\title{
The Effectiveness of Adobe Flash CS5 Learning Media on Explanatory Text Material in Public Senior High School 1 Padang Bolak
}

\author{
Riky Gunawan Siregar ${ }^{1}$, Mara Untung ${ }^{2}$, M.Oky Fardian Gafari ${ }^{2}$ \\ ${ }^{1}$ Master Student in Universitas Negeri Medan (Unimed), Medan, Indonesia \\ ${ }^{2}$ Lecturer in Universitas Negeri Medan (Unimed), Medan, Indonesia \\ rikygunawansiregarpahu@gmail.com
}

\begin{abstract}
The aims of this study is to find out the effectiveness of Adobe Flash CS5 Learning Media. This research was carried out in Public Senior High School 1 Padang, Bolak 2018/2019 Academic Year. Implementation of treatment (treatment) in the form of learning activities that are tailored to the education calendar. The population of this research and development are students of Public Senior High School 1 Padang Bolak. The result of this study The effectiveness of student learning outcomes tests got an average score of $81 \%$ with the criteria of "good" before using Adobe Flash CS5 learning media on learning to write explanatory texts got an average score of $68.7 \%$ with the criteria of "enough".
\end{abstract}

Keywords: effectiveness; explanatory text; adobe flash CS 5; learning media

\section{Introduction}

Writing skills are important skills for students in learning. Especially in the 2013 curriculum implemented, writing learning activities need to be further improved. Writing skills will be achieved if accompanied by continuous practice. The problem that arises in the field is that so far the teachers in the school pay less attention to writing lessons. Low student ability in writing causes learning goals that have been arranged are not achieved. This is in accordance with the opinion of Pelly, 1992 (Haryadi and Zamzami, 1996: 75) said that writing lessons that were once the main lessons and exercises now received less attention from students and teachers. Composing lessons as one aspect of learning Indonesian, especially writing skills are not handled seriously.

The results of direct observations made by researchers when the Indonesian language learning process took place in $11^{\text {th }}$ grade of Public Senior High School 1 Padang Bolak The researchers saw that the teaching teacher only used print media (textbooks) which caused students to feel bored so that they were less enthusiastic when the learning process took place. The atmosphere of learning in the classroom looks less attractive because only some students are active in the learning process. In addition there are several obstacles encountered in learning Indonesian. The constraint found in writing complex explanatory texts is that it is difficult for students to accept the learning because the learning of explanatory texts appears in the new curriculum. The problems that were also found, namely, students did not understand well the complex explanatory text and its characteristics, the explanation and specific guidance from the teacher were not found and the learning model used by the teacher was lacking in developing learning.

The interview results above concluded that the teacher did not yet have the skills to develop learning media by utilizing the facilities provided by the school. Teachers tend to only use printed media so that students are not motivated in learning because the ongoing learning process only uses the same learning media, namely textbooks.

Solutions to solve existing problems, teachers are required to be more creative in developing learning media, in an effort to improve the quality of learning in schools. One of the intended teacher creativity is being able to design various learning media that are suitable 
for certain learning. Sanjaya (2008: 23) states that the teacher can carry out the role as a facilitator in the learning process, many things must be understood in the use of various media and learning resources, including understanding various types of media and learning resources and the functions of each media, having skills in designing a media.

The use of instructional media that attracts more attention of students is expected to help students to improve their understanding and ways of writing complex explanatory texts. During this time, the majority of teachers only deliver material with lecture methods that have a monotonous and boring learning impact. Therefore, the presence of interactive multimedia in writing complex explanatory texts using Adobe Flash CS.5 is expected to help teachers to teach complex explanatory texts easily to students so students can understand learning material well. Learning media developed with Adobe Flash Pro CS5 has several advantages compared to other media, which can present material visually or audio visually followed by sound explanations, more interesting and enjoyable so that it can foster and increase student motivation in learning. In addition, the media can be used individually or classically. This learning media can also be used repeatedly, so students who do not understand the subject matter can repeat their learning activities independently, bearing in mind that each student has a different level of absorption.

\section{Review of Literature}

\subsection{Explanation Text}

The text in the 2013 curriculum is not interpreted as a form of written language. The text is a complete expression of the human mind in which there are situations and contexts). Halliday (in Muchtar, 2012: 89), "the text as a product is a text that is seen as an outcome that can be expressed with certain terms. The text is formed by the context of the situation of language use in which there is a register or variety of languages that underlie the birth of the text. "Blake Education (2006: 50) when the writer starts writing explanations, first the writer starts to determine the phenomena that exist, then explains why or how the phenomenon occur. The author must obtain a lot of content knowledge before starting to write explanatory texts.

Based on the opinions stated above it is concluded that explaining the process of the occurrence or formation of a natural or social phenomenon that arises an event before and as a boy.

There are various types of explanation based on the question of how and why. Examples of explanatory texts that explain an event or how something works, such as explaining how a lawn mower works, how technology describes a computer works, and how natural phenomena occur. Examples of explanatory texts that explain why something happens; among them explain why there is mist on the bathroom mirror when we shower, why the earth has gravity. But other types can explain the similarities and differences between objects, explain the procedure to read how to do something and detail how it works.

\subsection{Learning Media}

(Musfiqon, 2011: 26) Opinion Media comes from another language "medium" which literally means middle, intermediary, or introduction. A media in Arabic is an intermediary or message maker from the sender to the recipient of the media message are forms of communication both in print and audio visual and equipment that can be used to channel messages from the sender to the recipient so as to stimulate the thoughts, feelings, interest of 
students in such a way so the learning process occurs. Because of its position in the middle it can also be referred to as an introduction or liaison, namely delivering or connecting or channeling things from other sets of factors. The association of education communication technology (association of education and communication technology / AECT in America) limits the media as any form that is programmed for an information distribution process.

The association of education communication technology (association of education and communication technology / AECT in America) limits the media as any form that is programmed for an information distribution process. Whereas the national education association (NEA) has a different understanding. According to him the media are objects that are manipulated, seen, heard, read or discussed along with instruments that are used well in learning activities, can affect the effectiveness of instructional programs.

(Musfiqon, 2011: 26). Opinion learning media has different functions and types according to the tools that support the learning media. The following are theories about the understanding of instructional media, the criteria for selecting instructional media, the benefits of instructional media and the types of learning media.

\subsection{Adobe Flash CS5}

Flash is animation software released by Macromedia which has now been adopted by Adobe, Inc. Adobe Flash Professional CS5 is a version of Adobe Flash that has been updated from the previous version, i.e. Adobe Flash CS3 Professional, Adobe Flash CS4 Professional, and Adobe Flash Professional CS5.

Island Script (in Fatimah, 2016: 23-24) says Adobe Flash CS5 is animated graphics software that can create graphic objects and animate them so that we can directly create design objects without having to use supporting graphics software such as Illustrator or Photoshop. Adobe Flash Professional CS6 is equipped with a number of features that Adobe Flash did not have before, such as the bone tool that functions to create an animation of reinforcement by adding joint points to objects, 3D Rotation tool that functions to perform 3D rotation of objects based on the $\mathrm{X}, \mathrm{Y}$ axis, and $\mathrm{Z}$, as well as panel layout changes that make it easy for users to operate.

Adobe Flash Professional CS6 is software that is able to produce presentations, games, films, interactive CDs, and learning CDs, and to create interactive, interesting and dynamic websites. Adobe Flash CS6 is able to complement web sites with several kinds

animations, sounds, interactive animations, and others so that the user while listening to their explanation can see animated images, as well read explanations in text form. Adobe Flash CS5 as software for making interactive learning media based on some of its advantages (Ariesto Hadi Sutopo, 2003: 60).

\section{Research Method}

This research was carried out in Public Senior High School 1 Padang, Bolak 2018/2019 Academic Year. Implementation of treatment (treatment) in the form of learning activities that are tailored to the education calendar.

The population of this research and development are students of Public Senior High School 1 Padang Bolak. To see the effectiveness of the products developed, the researchers only took samples using cluster sampling techniques. Researchers took a sample of 30 students from Class XI. 


\section{Discussion}

The effectiveness of Adobe Flash CS5 learning media is known through the learning achievement test. The form of the test used to test the effectiveness of Adobe Flash CS5 learning media is an essay test. Taking the essay test is done in two stages, namely pretest and posttest. The purpose of the pretest is to find out the average initial ability of students before using Adobe Flash CS5 learning media in learning. While the posttest aims to determine the ability of students after the use of Adobe Flash CS5 learning media in learning.

Table 1. Data Learning Results Explanation Text

\begin{tabular}{|c|c|c|c|}
\hline \multirow[b]{2}{*}{ No } & \multirow[b]{2}{*}{ Student's name } & \multicolumn{2}{|c|}{ Student Assessment } \\
\hline & & Pretest & Posttest \\
\hline 1 & Alfina Damayanti & 60 & 70 \\
\hline 2 & Ainun Siregar & 65 & 82 \\
\hline 3 & Ali Okman & 55 & 68 \\
\hline 4 & Ali Yahya Situmorang & 59 & 68 \\
\hline 5 & Ardiman & 55 & 70 \\
\hline 6 & Azmar Ibrahim & 62 & 75 \\
\hline 7 & $\begin{array}{l}\text { DesliPublic Senior High } \\
\text { Schoolwati Harahap }\end{array}$ & 70 & 80 \\
\hline 8 & Hesti Mega Harahap & 72 & 80 \\
\hline 9 & Hotman Martondi & 78 & 82 \\
\hline 10 & Idris Harahap & 80 & 85 \\
\hline 11 & Irma siti Dewi Siregar & 77 & 89 \\
\hline 12 & Maimuna & 66 & 75 \\
\hline 13 & Maimuna & 82 & 90 \\
\hline 14 & Marlin Anggelina Harahap & 75 & 87 \\
\hline 15 & Mida Sari Siregar & 75 & 88 \\
\hline 16 & Minda Sari Siregar & 60 & 77 \\
\hline 17 & Mohammah Yusuf & 68 & 85 \\
\hline 18 & Noni Yusnaida Harahap & 63 & 87 \\
\hline 19 & Pardamean Siregar & 73 & 88 \\
\hline 20 & $\begin{array}{l}\text { RiPublic Senior High Schooln } \\
\text { Budiman }\end{array}$ & 70 & 82 \\
\hline 21 & Rudinus Ritonga & 68 & 75 \\
\hline 22 & Sahwan Putra Harahap & 82 & 90 \\
\hline 23 & Saida Sari Harahap & 80 & 90 \\
\hline 24 & Sarwedi Siregar & 56 & 70 \\
\hline 25 & Sera wati Siregar & 68 & 82 \\
\hline 26 & Siti Anni Siregar & 65 & 78 \\
\hline 27 & Syukron Zalzilah Sinaga & 75 & 90 \\
\hline 28 & Tukmaida Ritonga & 73 & 85 \\
\hline 29 & Wahyu Siregar & 77 & 87 \\
\hline 30 & Zulman Sinaga & 68 & 75 \\
\hline \multicolumn{2}{|c|}{ Total } & 2063 & 2430 \\
\hline \multicolumn{2}{|c|}{ Average } & 68,7 & 81 \\
\hline
\end{tabular}


Table 2. Frequency Distribution of Pretest Value Learning Outcomes for Writing Explanatory Texts before Using Learning Media Adobe Flash CS5

\begin{tabular}{|l|l|l|}
\hline Interval & Frequency & Presentation \\
\hline $55-59$ & 4 & $13,3 \%$ \\
\hline $60-64$ & 4 & $13,3 \%$ \\
\hline $65-69$ & 8 & $26,6 \%$ \\
\hline $70-74$ & 5 & $16,6 \%$ \\
\hline $75-79$ & 6 & $20 \%$ \\
\hline $80-84$ & 3 & $10 \%$ \\
\hline$\sum$ & $\mathbf{3 0}$ & $\mathbf{1 0 0 \%}$ \\
\hline
\end{tabular}

Table 3. Posttest Value Frequency Distribution Learning Outcomes to Write Explanatory Text after Using Learning Media Adobe Flash CS5

\begin{tabular}{|l|l|l|}
\hline Interval & Frequency & Presentation \\
\hline $65-69$ & 2 & $6,6 \%$ \\
\hline $70-74$ & 3 & $10 \%$ \\
\hline $75-79$ & 6 & $20 \%$ \\
\hline $80-84$ & 6 & $20 \%$ \\
\hline $85-89$ & 9 & $30 \%$ \\
\hline $90-94$ & 4 & $13,3 \%$ \\
\hline$\sum$ & $\mathbf{3 0}$ & $\mathbf{1 0 0 \%}$ \\
\hline
\end{tabular}

The effectiveness of the lecture method used in the learning process in schools obtained a score of 2063 with an ideal score of 3000 , and then the acquisition scores are as follows:

Effectiveness $=\frac{\text { Total score obtained }}{\text { The ideal score }} X 100$

$$
=\frac{2063}{3000} \times 100=68,7 \%
$$

While the effectiveness of Adobe Flash CS5 media with developed scores obtained 2063 with an ideal score of 3000, then the acquisition scores, the acquisition scores are as follows:

Effectiveness $=\frac{\text { Total score obtained }}{\text { The ideal score }} X 100$

$$
=\frac{2430}{3000} \times 100=81 \%
$$

The percentage difference between pretest and posttest is $12 \%$ with a better posttest than pretest. Thus, the effectiveness contribution from the use of digital modules with explanatory text material is $12 \%$. So it can be concluded that Adobe Flash CS5 media developed is more effective by $81 \%$ with a good category and the effectiveness of the student lecture method by $68.7 \%$ with a sufficient category. So Adobe Flash CS5 is declared effective as an additional learning media for students in writing explanatory text. 
Table 4. Summary of Pretest and Posttest Average Values

\begin{tabular}{|l|l|l|l|}
\hline No & Group & Average value & Difference \\
\hline 1 & Before (Pretest) & 68,7 & \multirow{2}{*}{12} \\
\hline 2 & After (Postest) & 81 & 12 \\
\hline
\end{tabular}

The table above shows that the difference from pretest to posttest scores was 12 , with an average pretest of 68.7 in the "enough" criteria and an average of 81 in the "good" criteria. It can be concluded that learning using Adobe Flash CS5 media can improve student learning outcomes in learning Indonesian, especially the material to write explanatory texts.

After the pretest and posttest are carried out, then in the development phase a student learning motivation questionnaire is conducted involving 30 students of class XI-IPA1. The point is given the students 'learning motivation questionnaire to see how students' interests or responses in the learning process use Adobe Flash CS5 learning media. Can be seen in the following table 4.11

Table 5. Limited Try Out Results Data on Student Motivation

\begin{tabular}{|l|l|l|l|l|l|l|}
\hline \multirow{2}{*}{ No } & \multirow{2}{*}{ Questions } & \multicolumn{3}{|l|}{$\begin{array}{l}\text { The answer of } \\
\text { Respondents }\end{array}$} & \multicolumn{1}{l|}{$\begin{array}{l}\text { Total } \\
\text { Score }\end{array}$} \\
\cline { 3 - 8 } & & SS & S & KS & TS & \\
\hline 1 & $\begin{array}{l}\text { At the beginning of this lesson, my } \\
\text { impression was not interesting }\end{array}$ & 10 & 12 & 4 & 4 & 88 \\
\hline 2 & $\begin{array}{l}\text { At the beginning of following this } \\
\text { lesson, my impression of this lesson is } \\
\text { boring }\end{array}$ & 7 & 15 & 5 & 3 & 86 \\
\hline 3 & $\begin{array}{l}\text { Initially I was confused by the teacher's } \\
\text { explanation }\end{array}$ & 9 & 15 & 4 & 2 & 91 \\
\hline 4 & $\begin{array}{l}\text { After listening to the preliminary } \\
\text { information, I began to understand the } \\
\text { aims and objectives of learning. }\end{array}$ & 12 & 10 & 5 & 3 & 91 \\
\hline 5 & $\begin{array}{l}\text { When facing difficulties in subjects, I } \\
\text { try to find alternative solutions to } \\
\text { problems }\end{array}$ & 10 & 13 & 5 & 2 & 91 \\
\hline 6 & $\begin{array}{l}\text { I was impressed and motivated by the } \\
\text { way the teacher encouraged me to take } \\
\text { this lesson }\end{array}$ & 17 & 10 & 2 & 1 & 103 \\
\hline 7 & $\begin{array}{l}\text { The material is associated with } \\
\text { everyday problems }\end{array}$ & 16 & 11 & 2 & 1 & 102 \\
\hline 8 & $\begin{array}{l}\text { I feel happy when the teacher explains } \\
\text { using pictures, audio and animation }\end{array}$ & 22 & 5 & 1 & 1 & 106 \\
\hline 9 & $\begin{array}{l}\text { I sure can understand every lesson } \\
\text { taught by the teacher if using animation, } \\
\text { images and audio. }\end{array}$ & 22 & 6 & 1 & 1 & 109 \\
\hline 10 & $\begin{array}{l}\text { I feel this way of learning is suitable for } \\
\text { use in several other lessons }\end{array}$ & 21 & 7 & 2 & 1 & 110 \\
\hline Total Score & & & & $\mathbf{9 7 7}$ \\
\hline Score Percentage & & & & & & \\
\hline
\end{tabular}


Based on the results of the questionnaire calculations distributed to students to see student motivation in limited trials about the development of adobe flash CS5 learning media applied to explanatory text material, a total score of 977 was obtained with a percentage of $81.4 \%$ with Good criteria (B).

The deployment stage is the final stage in the 4-D process in the form of the distribution phase of Adobe Flash CS5 learning media that has been developed on a broader scale. The purpose of this stage is to test the effectiveness of using Adobe Flash CS5 learning media.

At this stage the trial of product development in a wider group. The trial was conducted on all students of class XI IPA of Public Senior High School 1 Padang Bolak namely XI-IPA1, XI-IPA2, XI-IPA3, XI-IPS1, XI-IPS2, amounting to 145 people. Data collected in this stage is data about the effectiveness of the development of adobe flash CS5 learning media on the motivation to learn to write explanatory texts by spreading the learning motivation questionnaire. Furthermore, the data obtained at this stage is used as a material to assess the effectiveness of the development of Adobe Flash CS5 learning media which is carried out on student motivation. Data obtained at this stage can be seen in table 4.12 below:

Table 6 Expanded Trial Results Data on Student Motivation

\begin{tabular}{|c|c|c|c|c|c|c|}
\hline \multirow[t]{2}{*}{ No } & \multirow[t]{2}{*}{ Question } & \multicolumn{4}{|c|}{$\begin{array}{l}\text { The answer } \\
\text { Respondents }\end{array}$} & \multirow{2}{*}{$\begin{array}{l}\text { Total } \\
\text { Score }\end{array}$} \\
\hline & & SS & $\mathbf{S}$ & KS & TS & \\
\hline 1 & $\begin{array}{l}\text { At the beginning of this lesson, my } \\
\text { impression was not interesting }\end{array}$ & 60 & 45 & 20 & 20 & 435 \\
\hline 2 & $\begin{array}{l}\text { At the beginning of following this } \\
\text { lesson, my impression of this lesson is } \\
\text { boring }\end{array}$ & 52 & 49 & 26 & 18 & 425 \\
\hline 3 & $\begin{array}{l}\text { Initially I was confused by the teacher's } \\
\text { explanation }\end{array}$ & 59 & 59 & 15 & 12 & 455 \\
\hline 4 & $\begin{array}{l}\text { After listening to the preliminary } \\
\text { information, I began to understand the } \\
\text { aims and objectives of learning }\end{array}$ & 70 & 46 & 15 & 14 & 462 \\
\hline 5 & $\begin{array}{l}\text { When facing difficulties in subjects, I } \\
\text { try to find alternative solutions to } \\
\text { problems }\end{array}$ & 72 & 48 & 17 & 8 & 474 \\
\hline 6 & $\begin{array}{l}\text { I was impressed and motivated by the } \\
\text { way the teacher encouraged me to take } \\
\text { this lesson }\end{array}$ & 79 & 50 & 8 & 8 & 490 \\
\hline 7 & $\begin{array}{l}\text { The material is associated with } \\
\text { everyday problems }\end{array}$ & 75 & 48 & 15 & 7 & 481 \\
\hline 8 & $\begin{array}{l}\text { I feel happy when the teacher explains } \\
\text { using pictures, audio and animation }\end{array}$ & 80 & 52 & 9 & 4 & 498 \\
\hline 9 & $\begin{array}{l}\text { I sure can understand every lesson } \\
\text { taught by the teacher if using animation, } \\
\text { images and audio. }\end{array}$ & 86 & 49 & 7 & 3 & 508 \\
\hline
\end{tabular}




\begin{tabular}{|l|l|l|l|l|l|l|}
\hline 10 & $\begin{array}{l}\text { I feel this way of learning is suitable for } \\
\text { use in several other lessons }\end{array}$ & 86 & 45 & 10 & 4 & 503 \\
\hline Total Score & & $\mathbf{4 7 3 1}$ \\
\hline
\end{tabular}

Based on the results of a questionnaire calculation to see student motivation in the expanded trial of the development of adobe flash learning media CS5 explanatory text obtained a total score of 4731 with a percentage of $81.5 \%$ with Good criteria (B). Then from the results of the motivation was declared effective by using Adobe Flash CS5 explanatory text learning media.

Analysis of the results of interviews conducted on two teachers and a number of students in class XI of Public Senior High School 1 Padang Bolak at the defining stage are as follows:

1. 26 students $(86.6 \%)$ said they did not know Adobe Flash CS5 learning media and $2(100 \%)$ teachers did not know Adobe Flash CS5 learning.

2. 30 students $(100 \%)$ said they did not use adobe flash CS5 learning media in explanatory text material and 2 teachers $(100 \%)$ did not use adobe flash CS5 in the learning process.

3. 28 students $(93.7 \%)$ said that they needed adobe flash CS5 learning media in written explanatory text material and 2 teachers (100\%) said they needed adobe flash CS5 learning media in the learning process.

Based on the results of student responses about learning media. So the need for learning media in the form of Adobe Flash CS5 to facilitate students in understanding explanatory texts. Because by using Adobe Flash CS5 will be interesting for students because it will stimulate the students' audio visual. For the results of the teacher's response, it is necessary to implement adobe flash CS5 learning media to make students interesting in learning explanatory texts. Because students will be more happy if the learning process has new innovations, and the learning will turn on the students' audio visual in learning.

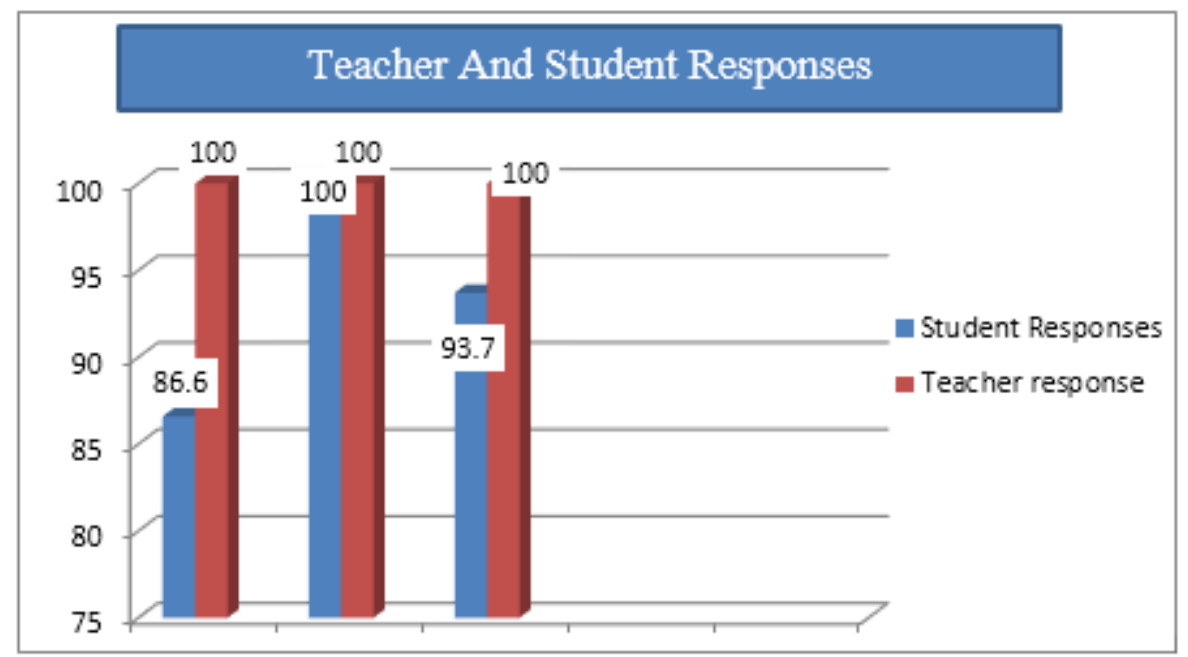

Figure 1. Teacher and Student Responses 
Commensurate with the research of Rita and Julaga Situmorang (2014) in their journal development of internet based interactive multimedia learning in English which says $82 \%$ of students are not familiar with interactive multimedia learning, $89 \%$ of students do not use interactive multimedia learning in the learning process, and $80 \%$ of students need learning interactive multimedia. So in line with the opinion of Rita and Julaga Situmorang (2014) that requires Adobe Flash CS5 learning media.

Pretest results of students before using Adobe Flash CS5 learning media with an average of $68.7 \%$ on the criteria of "enough" and for students' scores after using Adobe Flash CS5 learning media is $81 \%$ on the "good" criteria it can be concluded that learning using Adobe learning media Flash CS5 can improve student learning outcomes in learning Indonesian, especially writing explanatory text material.

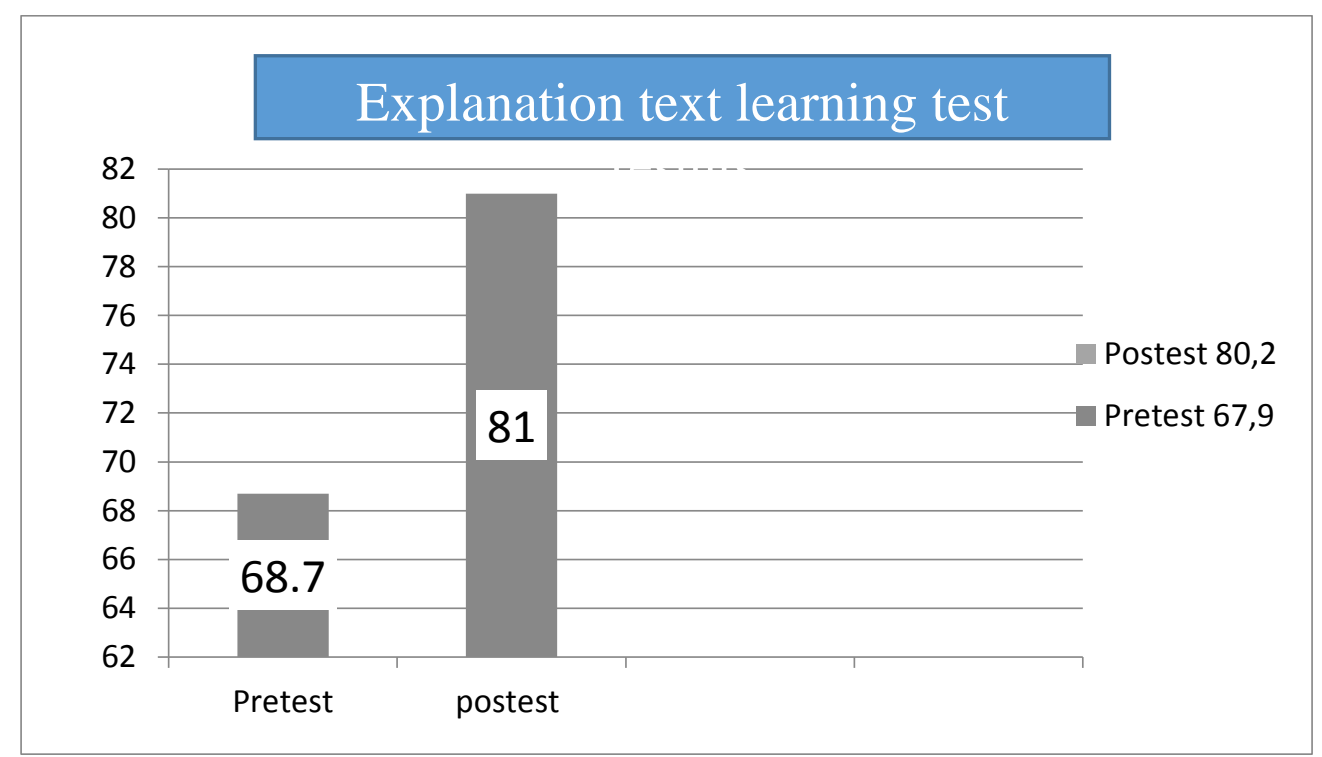

Figure 1. Explanation text learning test results

In line with the opinion of Rita (2014) in her journal development of internet-based interactive multimedia learning English lessons. That by using internet-based interactive multimedia has an effectiveness of $80.46 \%$ higher compared to textbooks only scored below KKM 75 of $71.72 \%$.

Furthermore, it is commensurate with the research of Nur Lailiyah (2018) "Development of Flash-Based Interactive Learning Media for Learning to Rewrite Story Skills of $6^{\text {th }}$ grade Elementary School Students" The results of the class pretest get an average score of 68 with good criteria. While the posttest results showed an average score of 86 with very good criteria.

Thus, Adobe Flash CS5 learning media can increase the average value of students. Judging from the students' pretest and posttest grades. Then it is feasible to use in the learning system.

\section{Conclusion}

The effectiveness of student learning outcomes tests got an average score of $81 \%$ with the criteria of "good" before using Adobe Flash CS5 learning media on learning to write explanatory texts got an average score of $68.7 \%$ with the criteria of "enough". 


\section{References}

Amrulloh Rizki, et.al.(2013).Kelayakan Teoritis Media Pembelajaran Multimedia Interaktif Materi Mutasi untuk PUBLIC SENIOR HIGH SCHOOL. Jurnal Berkala Ilmiah Pendikan Bilogi. Vol.2 No 2

Arda, et.al.(2015). Pengembangan Media Pembelajaran Interaktif Berbasis Komputer untuk siswa SMP kelas. VIII. Vol.3. No.1

Arsyad, Azhar. (2011). Media Pembelajaran Edisi Revisi. Jakarta: Rajawali Press

Blake Education. (2006). Targetting Text. New South Wales: Blake Education

Daryanto, (2016). Media Pembelajaran. Bandung: PT. Sarana Tutorial Nurani Sejahtera

Istiqomah. (2011). Pengembangan Media Pembelajaran Interaktif Berbasis Adobe Flash Untuk Meningkatkan Penguasaan Eyd Pada Siswa Public Senior High School.

Kementrian Pendidikan dan Kebudayaan. (2014). Bahasa Indonesia Ekspresi Diri dan Akademik. Jakarta: Kementrian Pendidikan dan Kebudayaan.

Kosasih, E. (2014). Jenis-jenis Teks. Bandung: Yrama Widya

Kurniawati, Dewi. (2009). Pengembangan Bahan Ajar Bahasa dan Sastra Indonesia dengan Pendekatan Tematis. Pascasarjana Universitas Sebelas Maret Surakarta.

Lailiyah, Nur. (2018). Pengembangan Media Pembelajaran Interaktif Berbasis Flash Untuk Pembelajaran Keterampilan Menuliskan Kembali Cerita Siswa Kelas IV SD.

Madcoms. (2012). Dreamweaver CS5 dan PHP-MySQL untuk Pemula. Bandung: Andi

Musfiqon. 2011. Pengembangan Media dan Sumber Pembelajaran. Jakarta: PT. Prestasi Pustakarya.

Rita dan Julaga Situmorang. (2014). Pengembangan Pembelajaran Multimedia Interaktif Berbasis Internet Pelajaran Bahasa Inggris. PPS Universitas Negeri Medan. Jurnal teknologi informasi \& Komunikasi dalam pendidikan. Vol 4. No. 1

Sanjaya, Wina. (2006). Strategi Pembelajaran: Berorientasi Standar Proses Pendidikan. Jakarta: Kencana Prenada Media Group

Sugiyono. (2011). Metode Penelitian Pendidikan Pendekatan, Kualitatif, dan R\&D. Bandung: Alfabeta

Sugiyono. (2016). Metode Penelitian Pendidikan kuantitatif, Kualitatif, dan R\&D. Bandung: Alfabeta

Sukmadinata, Nana Syaodiah. (2008). Metode Penelitian Pendidikan. Bandung: PT Remaja Rosdakarya

Tarigan, Hanry Guntur. (2008). Menulis, Sebagai Suatu Keterampilan Berbahasa. Bandung: Angkasa.

Yogyantoro, Angger. (2016). Peningkatan Keterampilan Menulis Deskripsi Menggunakan Media Diorama Siswa Kelas IV. Jurnal Pendidikan Guru Sekolah Dasar 